\title{
Effects of food or nutrient restriction on milk vitamin A transfer and neonatal vitamin $A$ stores in the rat
}

\author{
BY ANA MARIA G. PASATIEMPO AND A. CATHARINE ROSS* \\ Division of Nutrition, Department of Physiology and Biochemistry, The Medical College of \\ Pennsylvania, 3300 Henry Avenue, Philadelphia, PA 19129, USA
}

(Received 22 March 1989 - Accepted 10 October 1989)

\begin{abstract}
We have investigated the effects of maternal diets low in fat or protein, or restricted in total food intake on vitamin A transfer from the dam to her pups. When animals were fed on diets moderately restricted in fat or protein, minimal differences in milk, serum, and liver vitamin A concentrations were observed compared with animals fed on a control diet. In a second study, dams were fed on diets more severely restricted in protein, or fat, or both, or were fed on a control diet equal to $50 \%$ of the intake of control rats but containing an equal amount of vitamin $A$. The quantity of milk obtained from these more severely restricted dams' nipples or the pups' stomachs was greatly reduced; however, there were no differences in milk vitamin A concentration. Body-weight, liver weight, and total liver vitamin A stores of undernourished pups were just half those measured for control pups, although serum vitamin $A$ and serum retinol-binding protein were nearly normal in concentration. We conclude that $(a)$ moderate restrictions in fat or protein in the maternal diet are insufficient to affect transfer of vitamin $A$ to the suckling pup; (b) further dietary restrictions could cause decreased milk production with little change in milk vitamin A concentration and, hence, $(c)$ the neonates' hepatic retinol accumulation during the suckling period is markedly reduced when maternal diets are severely deficient in fat or protein or of normal composition but restricted in amount.
\end{abstract}

Milk vitamin A: Neonatal undernutrition: Vitamin A: Rat

Intense changes in maternal metabolism occur during the periods of gestation and lactation to provide sufficient energy and nutrients to the mother and growing fetus. Maternal malnutrition during gestation has been reported to decrease the transfer of certain nutrients, compromising growth of the fetus (Rosso, 1977; Rosso \& Streeter, 1979), and to alter placental development influencing maternal-fetal exchange of nutrients (Rosso, 1981). Decreased placental weight (Laga et al. 1972a,b) and DNA content (Winick, 1970), as well as changes in placental morphology (Laga et al. 1972a,b) have also been observed. Consistent with these findings, undernutrition during pregnancy has been shown to increase the risk of abortion, premature delivery, and intrauterine growth retardation of the fetus (Baker et al. 1975).

Studies on the effects of undernutrition during lactation have been less consistent, indicating either relatively normal patterns of milk production or a reduction in the quantity of milk produced. The milk composition of marginally nourished mothers on uncontrolled diets was similar to that observed among well-nourished mothers, although milk volume was slightly lower and the concentration of certain nutrients was somewhat reduced (Brown et al. $1986 a, b$ ). Reductions in milk yield have been reported in the proteinrestricted or food-restricted rat (Grigor et al. 1987; Warman \& Rasmussen, 1983); however, concentrations of total lipid, protein and lactose in milk were not affected.

Vitamin A can be transferred from mother to offspring by two separate mechanisms:

* For reprints. 
passage through the placenta and secretion in the colostrum and milk. Early studies of the normal rat by Dann (1932) showed this latter route to be a better channel for vitamin A transport to the young than is the placental route. Takahashi et al. (1975) found that fetal vitamin A stores remained unaltered during marginal vitamin A intake of otherwise wellnourished dams having fairly depleted liver vitamin A stores. This suggests that vitamin A transport across the placenta is maintained even during maternal vitamin A deprivation. In contrast, during lactation the vitamin A content of the maternal diet clearly affects milk vitamin A concentration (Davila et al. 1985). When we fed normal rat dams on balanced diets containing differing levels of dietary vitamin $A$, we observed no differences in milk vitamin A concentration on the first day of lactation. However, as lactation progressed the vitamin A concentration of milk, as well as the liver vitamin A stores of the suckling pups, was significantly greater for those dams fed on a high-vitamin A diet (Davila et al. 1985).

Although vitamin A deficiency has been recognized as a complication of protein-energy malnutrition (PEM) among infants and children (Pereira et al. 1966; Reddy \& Srikantia, 1966; McLaren et al. 1969), little is known of whether the poor vitamin A status of these children is due in part to poor transfer of vitamin A from the malnourished mother to her offspring during pregnancy or lactation, or both. Studies of cord blood of infants of poor Ethiopian mothers (Gebre-Medhin et al. 1976) showed no difference in vitamin A and serum retinol-binding protein (RBP) concentrations even when maternal serum retinol was reduced, again indicating considerable homeostasis during gestation. However, the effects of specific deprivation of protein, fat or energy during lactation on milk vitamin A concentration and the establishment of neonatal reserves have not yet been explored. Therefore, it has been our goal in these studies to determine the effects of diets marginal or more severely deficient in either protein or fat, or restricted in total food intake, on milk vitamin A concentration and neonatal vitamin A stores.

\section{MATERIALS AND METHODS}

\section{Diets}

The compositions of diets for both studies are shown in Table 1. These diets were based on work of Clinton et al. (1984) and formulated so that the proportions of vitamins, minerals, and bulk on a per $\mathrm{kJ}$ diet basis remained constant despite some differences in the energy density of the various diets. For study 1, we prepared in powdered form: diet A, control diet containing a moderate amount of fat $(105 \mathrm{~g}$ maize oil $/ \mathrm{kg})$ and adequate protein $(226 \mathrm{~g}$ casein $/ \mathrm{kg})$; diet $\mathrm{B}$, low-fat diet $(50 \mathrm{~g}$ maize oil $/ \mathrm{kg})$; diet $\mathrm{C}$, low-protein diet $(110 \mathrm{~g}$ casein $/ \mathrm{kg}$ ); and diet $\mathrm{D}$, high-fat diet $(246 \mathrm{~g}$ maize oil $/ \mathrm{kg})$. The $50 \mathrm{~g}$ fat $/ \mathrm{kg}$ diet and the $110 \mathrm{~g}$ protein $/ \mathrm{kg}$ diet are within the lower range of the amounts of fat and protein adequate for reproduction and lactation as reported by the National Research Council Subcommittee on Laboratory Animal Nutrition (1978). A constant amount of vitamin A (14 nmol/g diet) in the form of retinyl palmitate (Sigma Chemical Co., St Louis, MO) was added into the maize oil before mixing into each diet. Analysis of vitamin $\mathrm{A}$ in these diets by highperformance liquid chromatography (HPLC) showed that all retinol concentrations were within the range of $14-16 \mathrm{nmol} / \mathrm{g}$ diet.

In study 2, diets more severely limiting in fat and protein were prepared for us in pelleted form by Research Diets Inc. (New Brunswick, NJ). Each diet (except diet $\mathrm{H}$ ) contained $7 \mathrm{nmol} \mathrm{retinol} / \mathrm{g}$ diet. The four diets that were compared were: diet $\mathrm{E}$, control diet the same as $\operatorname{diet} \mathrm{A}$, but with reduced retinol $(2 \mathrm{nmol} / \mathrm{g})$; diet $\mathrm{F}$, very-low-protein diet $(60 \mathrm{~g}$ casein $/ \mathrm{kg}$ ); diet $\mathrm{G}$, very-low-protein-very-low-fat diet (60 g casein and $20 \mathrm{~g}$ maize oil $/ \mathrm{kg}$ ); and diet $\mathrm{H}$, control diet with $14 \mathrm{nmol} \mathrm{retinol} / \mathrm{g}$ diet, but provided at $50 \%$ of the amount consumed (designated as $50 \%$ restricted) by rats fed on diet $\mathrm{E}$ ad lib. The $60 \mathrm{~g} / \mathrm{kg}$ level of 


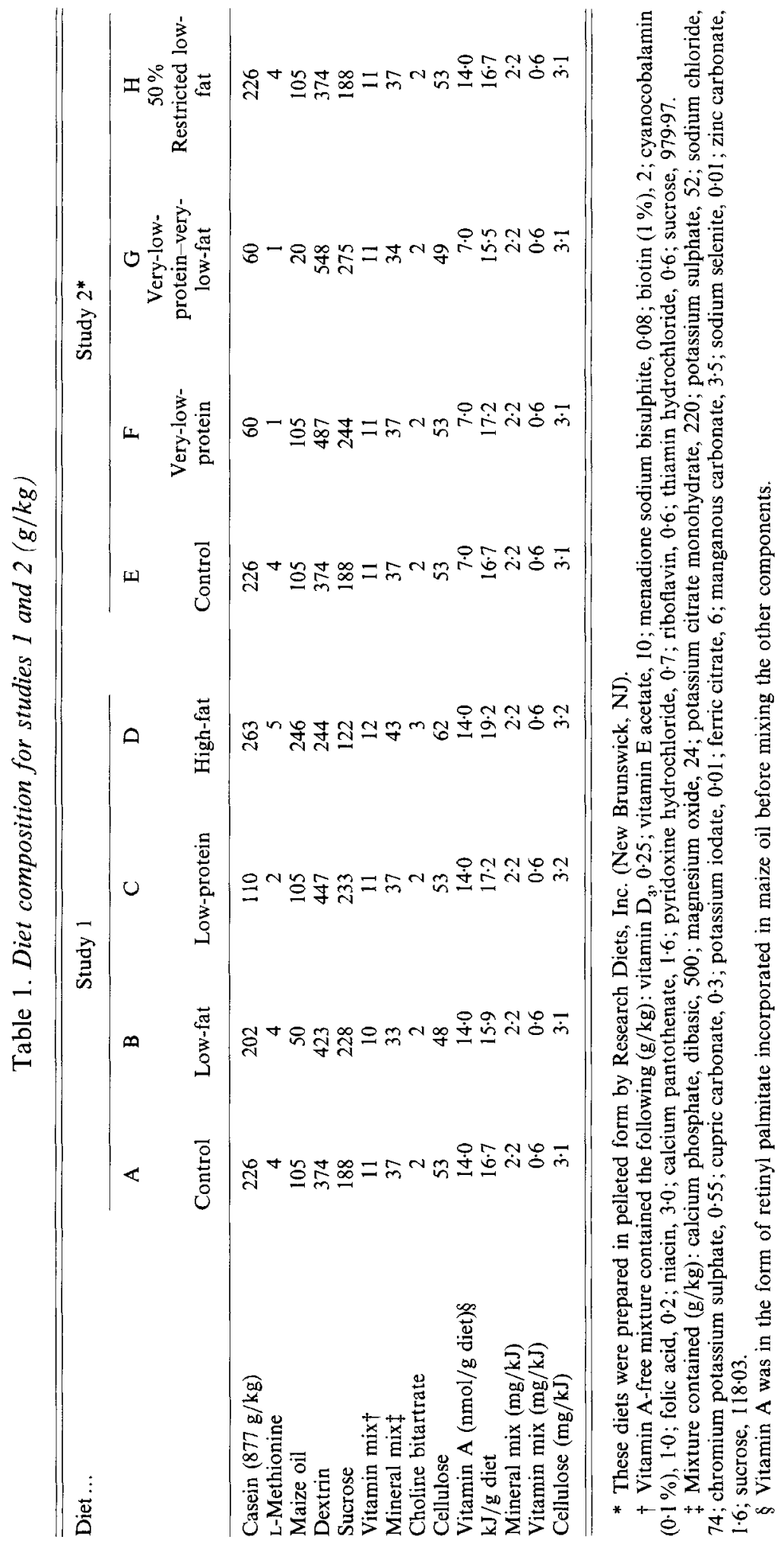


casein was selected based on the minimum amount of protein necessary for reproduction (Nelson \& Evans, 1953). The $20 \mathrm{~g}$ maize oil $/ \mathrm{kg}$ used was based on the calculation that if lactating dams need $0.3 \%$ of their energy as linoleic acid (Rogers, 1979), a $20 \mathrm{~g}$ maize oil $/ \mathrm{kg}$ diet (since maize oil contains approximately $50 \%$ linoleic acid) would be adequate to provide the minimum level of essential fatty acids. Diets were stored at $4^{\circ}$.

\section{Animals and experimental design}

Female Sprague-Dawley rats were purchased from Charles River Breeding Laboratories (Kingston, NY), and were housed and bred in our facility as previously described (Davila et al. 1985). In study 1 , thirty-three adult female rats $(176-200 \mathrm{~g})$ were divided into four dietary groups and were fed on their respective diets from $3 \mathrm{~d}$ before breeding, throughout pregnancy, and during $14 \mathrm{~d}$ of lactation, a total of approximately $38 \mathrm{~d}$. Diet was given in powdered form and was weighed and changed every $3-4 \mathrm{~d}$. On the first day that pups were found, designated as day 1 of lactation, litter size was reduced, or in a few cases increased, to eight pups per dam by removing or transferring extra pups within a diet group. Pups unassigned on day 1 were anaesthetized with diethyl ether and their livers were collected, pooled within litters, and analysed for liver vitamin A. Milk samples were collected by manual expression on days 1, 8, and 14 of lactation as previously described (Davila et al. 1985). We ended our studies on day 14 of lactation to prevent direct consumption of maternal diet by the young pups.

In study 2 , forty weanling female rats were fed on the control diet containing $2 \mathrm{nmol}$ vitamin $\mathrm{A} / \mathrm{g}$ diet until they were about $55 \mathrm{~d}$ of age to limit vitamin $\mathrm{A}$ accumulation prior to pregnancy and lactation. At this time, they were bred (Davila et al. 1985). Following the experience of others (Nelson \& Evans, 1953; Rosso, 1977; Rosso \& Streeter, 1979), to maximize conception and minimize fetal resorption, all animals were maintained on this diet until the middle of the breeding period when they were placed in individual cages and were assigned to one of the four diets. In the present study, we collected milk from nipples of dams on days 2 and 14 and from milk curd (stomach contents) of extra pups, pooled within a litter, on day 2 and from all pups on day 14 .

\section{Analysis of vitamin $A$ in serum, milk, and liver}

Total vitamin A in serum, milk and liver homogenates was determined by the HPLC procedure described previously using a known amount of trimethylmethoxyphenylretinol as internal standard (Pasatiempo et al. 1989).

\section{Serum RBP determination by radial immunodiffusion}

Serum RBP was measured for both dams and pups by the radial immunodiffusion technique (Mancini et al. 1965) using $10 \mathrm{~g}$ agarose $/ \mathrm{kg}$ containing $150 \mathrm{~g}$ polyethylene glycol/kg and rabbit-anti-rat serum RBP (Sklan \& Ross, 1987) diluted to a final concentration of 1:40. Rat RBP standards were included on each plate. After immunoprecipitate rings developed to their maximum size, gels were washed and dried, and stained with Amido black. Ring diameters were measured and compared with the RBP standards.

\section{Statistical analysis}

Values are presented as the mean with 1 SEM. All values were analysed by a one-way analysis of variance using the Statistical Program for the Apple II Microcomputer (Steimmetz et al. 1981). Details of individual statistical analyses are presented in the accompanying footnote to the appropriate table. 


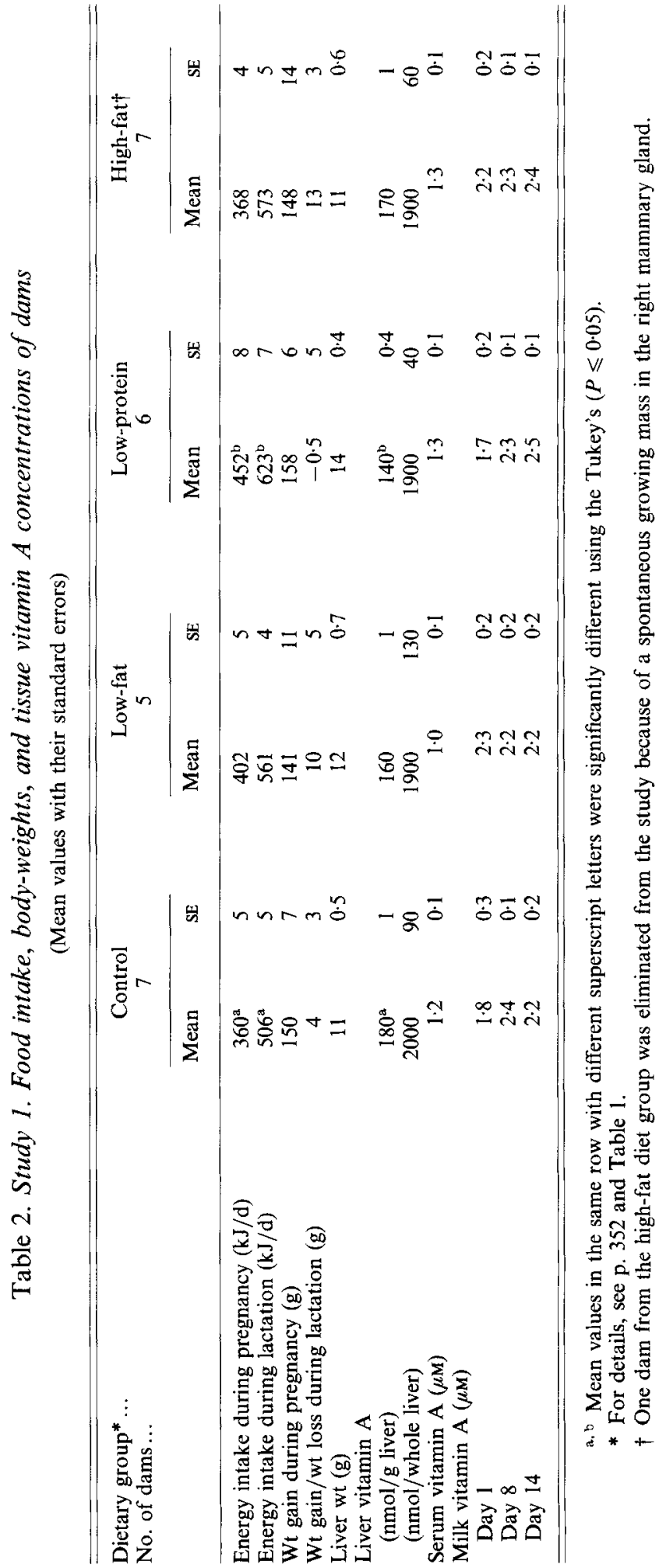


Table 3. Study 1. Body-weights and tissue vitamin A concentrations of pups

(Mean values with their standard errors)

\begin{tabular}{|c|c|c|c|c|c|c|c|c|}
\hline \multirow[t]{2}{*}{$\begin{array}{l}\text { Dietary group* } \ldots \\
\text { No. of litters } † \ldots\end{array}$} & \multicolumn{2}{|c|}{$\begin{array}{c}\text { Control } \\
7\end{array}$} & \multicolumn{2}{|c|}{$\begin{array}{c}\text { Low-fat } \\
5\end{array}$} & \multicolumn{2}{|c|}{$\begin{array}{c}\text { Low-protein } \\
6\end{array}$} & \multicolumn{2}{|c|}{$\begin{array}{c}\text { High-fat } \\
7\end{array}$} \\
\hline & Mean & SE & Mean & SE & Mean & SE & Mean & SE \\
\hline \multicolumn{9}{|l|}{ Body-wt (g) } \\
\hline Day 1 & 6 & $0 \cdot 1$ & 6 & $0 \cdot 3$ & 6 & $0-2$ & 6 & $0-2$ \\
\hline Day 8 & 15 & 0.5 & 15 & 0.4 & 14 & $0 \cdot 3$ & 15 & 0.6 \\
\hline Day 14 & 24 & 0.9 & 24 & $0 \cdot 6$ & 23 & 0.6 & 25 & 0.9 \\
\hline Serum vitamin $\mathrm{A}(\mu \mathrm{M})$ & 0.94 & 0.07 & $0 \cdot 83$ & 0.01 & 0.87 & 0.03 & 0.79 & 0.03 \\
\hline \multicolumn{9}{|l|}{ Day 1} \\
\hline Liver wt (g) & $0 \cdot 24$ & $0 \cdot 01$ & $0 \cdot 25$ & 0.01 & 0.25 & 0.01 & $0 \cdot 25$ & 0.01 \\
\hline \multicolumn{9}{|l|}{ Liver vitamin A } \\
\hline$(\mathrm{nmol} / \mathrm{g})$ & 48 & 2 & 51 & 3 & 49 & 1 & 54 & 3 \\
\hline (nmol/whole liver) & 12 & 1 & 13 & 1 & 12 & 0 & 14 & 1 \\
\hline \multicolumn{9}{|l|}{ Day 14} \\
\hline Liver wt (g) & $0-67$ & $0 \cdot 04$ & 0.68 & $0 \cdot 02$ & 0.65 & $0 \cdot 02$ & $0 \cdot 69$ & 0.03 \\
\hline \multicolumn{9}{|l|}{ Liver vitamin A } \\
\hline$(\mathrm{nmol} / \mathrm{g})$ & 79 & 5 & 70 & 3 & 88 & 4 & 79 & 2 \\
\hline (nmol/whole liver) & 53 & 3 & 48 & 2 & 57 & 2 & 55 & 3 \\
\hline
\end{tabular}

* For details, see p. 352 and Table 1.

$\dagger$ Each litter consisted of eight pups.

\section{RESULTS}

Study 1 was designed to determine whether moderate restrictions in fat or protein could affect milk vitamin A concentration or vitamin A accumulation by the pups. A high-fatdiet group was also included to find whether more than adequate amounts of dietary fat would facilitate vitamin $\mathrm{A}$ assimilation sufficiently to increase milk vitamin A concentration. Successful pregnancies and deliveries were achieved by seven of the eight rats fed on the control diet, all of the eight rats fed on the high-fat diet, five of the eight rats fed on the low-fat diet, and six of the nine rats fed on the low-protein diet. As shown in Tables 2 and 3, these diets produced relatively few differences in growth or tissue vitamin A contents. Total liver vitamin A and serum vitamin A concentrations were not different among the four treatment groups. Similarly, the retinol concentration in milk, measured on days 1,8 , and 14 of lactation, was not lower in the animal moderately restricted in fat or protein. Feeding the high-fat diet to lactating dams did not result in an increase in milk vitamin A concentration, although milk from these dams had a greater concentration of long-chain polyunsaturated fatty acids (A. M. G. Pasatiempo \& A. C. Ross, unpublished results) indicating greater utilization of the polyunsaturated dietary fat for milk fat production.

Body-weights and tissue vitamin A concentrations of pups in our first study are shown in Table 3. Body-weights of pups on days 1,8 and 14 of age were not significantly different among groups, although pups from dams fed on the low-protein diet tended to weigh slightly less than pups from the other groups. The serum and liver vitamin A concentrations of the suckling young were also unaffected by maternal diet. Pups from dams in all four diet groups accumulated significant amounts of vitamin $\mathbf{A}$ in their livers from birth (average of $13 \mathrm{nmol} /$ liver) to day 14 of age (average of $53 \mathrm{nmol} /$ liver), a four-fold increase during the suckling period.

In study 2 , we examined the effects of diets more severely restricted in fat, protein, or 
Table 4. Study 2. Food intake, body-weights, and tissue vitamin A concentration of dams

(Mean values with their standard errors)

\begin{tabular}{|c|c|c|c|c|c|c|c|c|}
\hline \multirow[t]{2}{*}{$\begin{array}{l}\text { Dietary group*. } \\
\text { No. of dams... }\end{array}$} & \multicolumn{2}{|c|}{$\begin{array}{l}\text { Control } \\
8\end{array}$} & \multicolumn{2}{|c|}{$\begin{array}{c}\text { Very-low- } \\
\text { protein } \\
7\end{array}$} & \multicolumn{2}{|c|}{$\begin{array}{c}\text { Very-low- } \\
\text { protein-very- } \\
\text { low-fat }{ }^{\dagger} \\
5\end{array}$} & \multicolumn{2}{|c|}{$\begin{array}{c}50 \% \\
\text { Restricted } \\
5\end{array}$} \\
\hline & Mean & SE & Mean & $\mathrm{SE}$ & Mean & SE & Mean & $\mathrm{SE}$ \\
\hline $\begin{array}{l}\text { Energy intake during } \\
\text { pregnancy }(\mathrm{kJ} / \mathrm{d})\end{array}$ & 297 & 3 & 314 & 2 & 314 & 5 & $151 \ddagger$ & - \\
\hline $\begin{array}{l}\text { Energy intake during } \\
\text { lactation }(\mathrm{kJ} / \mathrm{d})\end{array}$ & $502^{a}$ & 8 & $347^{\mathrm{b}}$ & 4 & $310^{\mathrm{b}}$ & 3 & $251 \ddagger$ & - \\
\hline $\begin{array}{l}\text { Wt gain during } \\
\text { pregnancy }(\mathrm{g})\end{array}$ & $110^{\mathrm{a}}$ & 2 & $104^{\mathrm{a}}$ & 7 & $102^{\mathrm{a}}$ & 10 & $45^{\mathrm{b}}$ & 5 \\
\hline $\begin{array}{l}\text { Wt gain/wt loss during } \\
\text { lactation }(\mathrm{g})\end{array}$ & $5^{\mathrm{a}}$ & 4 & -16 & 7 & $-36^{\mathrm{b}}$ & 8 & $\mathrm{I}^{\mathrm{a}}$ & 9 \\
\hline Liver wt (g) & $12^{\mathrm{a}}$ & 1 & $13^{\mathrm{a}, \mathrm{b}}$ & 1 & $17^{\mathrm{b}}$ & 1 & $7^{\mathrm{c}}$ & 1 \\
\hline $\begin{array}{l}\text { Liver vitamin A } \\
\text { (nmol/liver) }\end{array}$ & $366^{\mathrm{a}}$ & 2 & $285^{\mathrm{a}}$ & 3 & $152^{\mathrm{b}}$ & 2 & $373^{\mathrm{a}}$ & 4 \\
\hline (nmol/whole liver) & $4350^{\mathrm{a}}$ & 30 & $3480^{\mathrm{b}}$ & 20 & $2440^{\mathrm{h}}$ & 30 & $2930^{\mathrm{b}}$ & 10 \\
\hline Serum vitamin $\mathrm{A}(\mu \mathrm{M})$ & 10 & 0.2 & 1.5 & 0.2 & 1.5 & $0 \cdot 2$ & $1 \cdot 3$ & $0 \cdot 3$ \\
\hline Serum RBP $(\mu \mathrm{M})$ & 1.4 & $0 \cdot 1$ & $1 \cdot 7$ & 0.2 & 1.6 & 0.1 & $1 \cdot 1$ & 0.2 \\
\hline
\end{tabular}

RBP, retinol-binding protein.

$\mathrm{a}, \mathrm{b}, \mathrm{c}$ Mean values in the same row with different superscript letters were significantly different using the Tukey's test $(P \leqslant 0-05)$.

* For details, see p. 352 and Table 1.

$\dagger$ One dam from the very-low-protein-very-low-fat diet was accidentally killed and died on day 2 of lactation and, thus, was entirely eliminated from the study.

$\ddagger$ These values represented $50 \%$ of the amount of food consumed by the ad lib-fed control rats.

energy. Vitamin A was held constant at $7 \mathrm{nmol} / \mathrm{g}$ diet for all treatment groups except the $50 \%$ food restricted group for which the diet contained $14 \mathrm{nmol} / \mathrm{g}$ diet, thus equalizing total vitamin A intake. In agreement with what others have reported for severely restricted groups (Warman \& Rasmussen, 1983), the rate of successful pregnancies was reduced among rats fed on these severely restricted diets: eight of ten for rats fed the control diet, seven of ten for rats fed on the very-low-protein diet, six of ten for rats fed the very-lowprotein-very-low-fat diet, and five of ten for rats restricted to $50 \%$ of the control diet.

Food intake and gain or loss of body weight for dams are shown in Table 4. During pregnancy, the food intake of dams fed on the very-low-protein diet or the very-lowprotein-very-low-fat diet was similar to the food intake of control dams. However, during lactation these dams consumed less food than the controls and lost a significant amount of their body weight. As expected, dams from the $50 \%$ food restricted group gained significantly less weight during pregnancy. However, during lactation, these animals neither gained nor lost additional weight.

In addition to the significant reduction in body weight of these severely nutrient restricted dams, we also observed differences in their liver weight and morphology. The livers of dams fed on the very-low-protein and the very-low-protein-very-low-fat diets were heavier and larger in size than the livers of control and $50 \%$ food restricted dams (Table 4), although the weight differences between the control and very-low-protein groups did not reach statistical significance. These livers, most remarkably those from dams fed on the very-low-protein-very-low-fat diet, were grossly infiltrated with fat. Total vitamin A stores of severely restricted dams were lower than those of controls but were still within the range 
Table 5. Study 2. Mammary gland weight and milk vitamin A concentration

(Mean values with their standard errors)

\begin{tabular}{|c|c|c|c|c|c|c|c|c|}
\hline \multirow[t]{2}{*}{$\begin{array}{l}\text { Dietary group }{ }^{*} . . \\
\text { No. of dams ... }\end{array}$} & \multicolumn{2}{|c|}{$\begin{array}{c}\text { Control } \\
8\end{array}$} & \multicolumn{2}{|c|}{$\begin{array}{l}\text { Very-low- } \\
\text { protein } \\
7\end{array}$} & \multicolumn{2}{|c|}{$\begin{array}{c}\text { Very-low- } \\
\text { protein-very- } \\
\text { low-fat } \\
5\end{array}$} & \multicolumn{2}{|c|}{$\begin{array}{c}50 \% \\
\text { Restricted } \\
5\end{array}$} \\
\hline & Mean & $\mathrm{SE}$ & Mean & $\mathrm{SE}$ & Mean & $\mathrm{SE}$ & Mean & $\mathbf{S E}$ \\
\hline $\begin{array}{l}\text { Mammary gland wt (g) } \\
\text { Milk vitamin A (nmol/g milk)t }\end{array}$ & $9 \cdot 7^{\mathrm{a}}$ & 0.6 & $5 \cdot 5^{b}$ & 0.4 & $5 \cdot 5^{\mathrm{b}}$ & $0 \cdot 3$ & $3 \cdot 5^{\mathrm{b}}$ & 0.3 \\
\hline $\begin{array}{l}\text { Day } 2 \\
\text { Day } 8 \\
\text { Day } 14\end{array}$ & $\begin{array}{l}2 \cdot 0 \\
2 \cdot 3^{\mathrm{a}} \\
1 \cdot 8^{\mathrm{a}}\end{array}$ & $\begin{array}{l}0 \cdot 5 \\
0 \cdot 1 \\
0 \cdot 1\end{array}$ & $\begin{array}{l}2 \cdot 3 \\
3 \cdot 4^{\mathrm{b}} \\
3 \cdot 4^{\mathrm{b}}\end{array}$ & $\begin{array}{l}0 \cdot 4 \\
0 \cdot 3 \\
0 \cdot 4\end{array}$ & $\begin{array}{l}2 \cdot 0 \\
3 \cdot 3^{\mathrm{b}} \\
3 \cdot 6^{\mathrm{b}}\end{array}$ & $\begin{array}{l}0 \cdot 2 \\
0 \cdot 3 \\
0 \cdot 3\end{array}$ & $\begin{array}{l}1 \cdot 8 \\
2 \cdot 8 \\
3 \cdot 4^{b}\end{array}$ & $\begin{array}{l}0.2 \\
0 \cdot 3 \\
0 \cdot 9\end{array}$ \\
\hline $\begin{array}{l}\text { Vitamin A from milk curds } \\
\text { (pups' stomachs) } \\
\text { Day } 2 \\
\text { (nmol/g curd) }\end{array}$ & $2 \cdot 1$ & 0.6 & 1.0 & 0.1 & 1.3 & $0-2$ & $2 \cdot 8$ & 0.6 \\
\hline $\begin{array}{l}\text { Day } 14 \\
\text { (nmol/g curd) } \\
\text { (nmol/total milk curd) }\end{array}$ & $\begin{array}{l}2 \cdot 3 \\
1 \cdot 2^{\mathrm{a}}\end{array}$ & $\begin{array}{l}0 \cdot 1 \\
0 \cdot 2\end{array}$ & $\begin{array}{l}2 \cdot 0 \\
0 \cdot 3^{\mathrm{b}}\end{array}$ & $\begin{array}{l}0.3 \\
0.3\end{array}$ & $\begin{array}{l}2 \cdot 7 \\
0 \cdot 3^{\mathrm{b}}\end{array}$ & $\begin{array}{l}0.3 \\
0.0\end{array}$ & $\begin{array}{l}3 \cdot 4 \\
0.7^{\mathrm{b}}\end{array}$ & $\begin{array}{l}0.1 \\
0.5\end{array}$ \\
\hline
\end{tabular}

${ }^{a}, b$ Mean values in the same row with different superscript letters were significantly different using the Tukey's test $(P \leqslant 0.05)$.

* For details, see p. 352 and Table 1.

$\uparrow$ Represent the wet tissue weights of bilateral inguinal mammary glands.

\$ Milk samples were obtained by manual expression from each nipple of the lactating rat.

$\S$ Samples were obtained as milk curds from pups' stomachs $1 \mathrm{~h}$ after nursing with their dams. Samples were pooled per litter.

of liver stores adequate to maintain a normal concentration of serum vitamin A and RBP (Table 4).

Mammary gland weights and milk vitamin A concentrations are presented in Table 5. The mammary glands of dams fed on either the $50 \%$ food restricted diet or specific nutrient restricted diets were smaller and less developed compared with mammary glands of dams fed on the control diet. In this study, we attempted to collect milk samples from the dams' nipples by manual expression of milk as in study 1 and from the pups' stomach contents (milk curds). As shown in Table 5, the vitamin A concentration in the milk of control dams (compared by weight because of milk curdling) was comparable whether samples were obtained from the dam's nipple or from the suckling pups' stomachs. On the other hand, consistent with what others have reported (Fellows \& Rasmussen, 1984), milk from our nutrient and food restricted rats had a higher concentration of vitamin A compared with values obtained from control rats. Milk from these restricted rats appeared to be very thick, fatty and viscous. On the very-low-protein and the very-low-protein-very-low-fat diets, the average vitamin A concentration obtained from stomach milk curds was only $50-60 \%$ that of control animals on day 2; however, variance was quite large and thus these differences were not statistically significant. However, by day 14 the total amount of vitamin $A$ in the stomach of these restricted pups was markedly less than that for control pups, because these restricted pups had smaller stomach contents (Table 5).

Although severe maternal dietary restrictions during gestation had little effect on the weights of the newborn, growth failure became increasingly apparent as the suckling period progressed. By day 14 of age, pups nursed by dams fed on each of the three restricted diets 
Table 6. Study 2. Body and liver weights, vitamin A and retinol-binding (RBP) concentrations of pups

(Mean values with their standard errors)

\begin{tabular}{|c|c|c|c|c|c|c|c|c|}
\hline \multirow[t]{2}{*}{$\begin{array}{l}\text { Dietary group* } \ldots \\
\text { No. of litters } \dagger \ldots\end{array}$} & \multicolumn{2}{|c|}{$\begin{array}{c}\text { Control } \\
8\end{array}$} & \multicolumn{2}{|c|}{$\begin{array}{c}\text { Very-low- } \\
\text { protein } \\
7\end{array}$} & \multicolumn{2}{|c|}{$\begin{array}{c}\text { Very-low- } \\
\text { protein-very- } \\
\text { low-fat } \\
5\end{array}$} & \multicolumn{2}{|c|}{$\begin{array}{c}50 \% \\
\text { Restricted } \\
5\end{array}$} \\
\hline & Mean & $\mathrm{SE}$ & Mean & SE & Mean & SE & Mean & $\mathrm{SE}$ \\
\hline \multicolumn{9}{|l|}{ Body-wt (g) } \\
\hline Day 2 & $7 \cdot 5^{\mathrm{a}}$ & $0 \cdot 4$ & $6 \cdot 4$ & 0.5 & $6 \cdot 1$ & $0 \cdot 3$ & $5 \cdot 1^{\mathrm{b}}$ & 0.1 \\
\hline Day 8 & $17^{\mathrm{a}}$ & 1 & $10^{\mathrm{b}}$ & 1 & $9^{b}$ & 1 & $9^{\mathrm{b}}$ & 6 \\
\hline Day 14 & $28^{\mathrm{a}}$ & 2 & $14^{\mathrm{b}}$ & 1 & $11^{\mathrm{b}}$ & 1 & $13^{\mathrm{b}}$ & 1 \\
\hline \multicolumn{9}{|l|}{ Day $2 \ddagger$} \\
\hline Liver wt (g) & $0 \cdot 25$ & $0 \cdot 02$ & 0.22 & 0.02 & $0 \cdot 19$ & 0.01 & $0 \cdot 19$ & 0.00 \\
\hline Liver vitamin $\mathbf{A}$ & & & & & & & & \\
\hline (nmol/g liver) & 37 & 3 & 43 & 2 & 43 & 1 & 45 & 4 \\
\hline (nmol/whole liver) & 9 & 1 & 9 & 10 & 8 & 1 & 9 & 1 \\
\hline \multicolumn{9}{|l|}{ Day 14} \\
\hline Liver wt (g) & $0 \cdot 85^{\mathrm{a}}$ & 0.11 & $0.45^{\mathrm{b}}$ & 0.02 & $0 \cdot 30^{\mathrm{b}}$ & 0.02 & $0 \cdot 34^{\mathrm{b}}$ & 0.02 \\
\hline Liver vitamin $\mathrm{A}$ & & & & & & & & \\
\hline (nmol/g liver) & $56^{\mathrm{a}}$ & 2 & $94^{\mathrm{b}}$ & 6 & $102^{\mathrm{b}}$ & 4 & $60^{\mathrm{a}}$ & 3 \\
\hline (nmol/whole liver) & $46^{a}$ & 3 & $32^{\mathrm{b}}$ & 1 & $30^{\mathrm{b}}$ & 1 & $21^{\mathrm{b}}$ & 2 \\
\hline Serum vitamin A $(\mu \mathrm{M})$ & $1 \cdot 2^{\mathrm{a}}$ & $0 \cdot 1$ & $0.8^{b}$ & 0.1 & $1 \cdot 1$ & 0.1 & $0.8^{\mathrm{n}}$ & $0 \cdot 1$ \\
\hline Serum RBP $(\mu \mathrm{M})$ & $1 \cdot 2^{\mathrm{a}}$ & $0 \cdot 1$ & $1 \cdot 0$ & $0 \cdot 0$ & $0 \cdot 90^{\mathrm{b}}$ & $0 \cdot 1$ & 1.0 & $0 \cdot 1$ \\
\hline Retinol:serum RBP $(\mu \mathrm{mol} / \mu \mathrm{mol})$ & 0.9 & 0.1 & 0.8 & 0.2 & 1.2 & 0.4 & 0.9 & $0 \cdot 2$ \\
\hline
\end{tabular}

a.b Mean values in the same row with different superscript letters were significantly different using the Tukey's test $(P \leqslant 0.05)$.

* For details, see p. 352 and Table 1.

$\dagger$ Each litter consisted of eight pups. One litter in the $50 \%$ restricted diet group had only four pups by the end of the study as the other four pups died in the middle of the suckling period.

+ Livers obtained on day 2 were from the extra pups in a litter.

were just half the size of the control pups (Table 6). These deprived and malnourished pups appeared weak and lethargic.

Similarly, liver weights of pups in each dietary group were not significantly different on day 2 of lactation but by day 14 the livers of malnourished pups weighed significantly less (Table 6). Liver vitamin A stores of the pups in all four groups were equal on day 2 but, after 14 days suckling total vitamin $A$ stores were significantly lower in each restricted group. In spite of differences in liver vitamin A stores, the serum vitamin A and serum RBP concentrations were only slightly reduced in comparison with the well nourished pups.

\section{DISCUSSION}

The present studies have shown that moderate dietary restriction of fat or protein, in the lower range of fat and protein concentration necessary for reproduction and lactation (National Research Council Subcommittee on Laboratory Animal Nutrition, 1978), does not compromise maternal or fetal growth, the growth of the suckling pups, or the transfer of vitamin A from dams to pups as assessed by either milk vitamin A concentration or neonatal liver vitamin A reserves. However, when we further decreased the amounts of fat or protein, or both, in the maternal diet, numerous manifestations of malnutrition were observed for both the dams and their suckling young. Interestingly, some of these 
manifestations of malnutrition, particularly maintenance of maternal body mass and growth of the pups, differed among animals restricted in total food intake or restricted specifically in the protein or fat content, or both, of the ad lib.-fed diet. Vitamin A transfer in milk and vitamin $\mathbf{A}$ accumulation in the neonates were also affected.

The outcome of food or nutrient restriction during pregnancy has been discussed in detail by Rosso and co-workers (Rosso, 1977; Rosso \& Streeter, 1979; Rosso et al. 1981), who hypothesized that, during periods of reduced availability of nutrients, the mother protects her body stores from depletion by a combination of metabolic and physiological adaptations, including a reduced plasma volume expansion with concomitant reductions in uterine and placental blood perfusion. These changes could account for the decrease in nutrient transfer leading to fetal growth retardation (Rosso \& Streeter, 1979; Rosso, 1981) and are likely to explain the reduced fetal growth observed in our food-restricted animals. Thus, the low birth weight of offspring from malnourished mothers is likely to be secondary to the decrease in blood supply to the fetus, rather than a direct effect of reduced nutrient concentrations in maternal blood. Consistent with this hypothesis, dams in our study that were severely restricted in protein or fat, or both, or in total diet, had essentially normal concentrations of vitamin $\mathrm{A}$ in both serum and liver but, as discussed later, their offspring accumulated significantly lower reserves of retinol.

In preparation for lactation, the mammary glands normally undergo a hormonallyregulated, marked hyperplasia during pregnancy (Ceriani, 1974). Rosso et al. (1981) reported a marked decrease in mammary gland weight when rats were restricted to $50 \%$ of normal food intake during pregnancy. When we gave diets more severely restricted in fat or protein, or both, or of normal composition but restricted in quantity, the dams' mammary glands were very much underdeveloped by gross appearance and weight, and only a small amount of thick, viscous milk could be expressed. Extending Rosso's hypothesis (Rosso, 1977; Rosso \& Streeter, 1979; Rosso et al. 1981) into the lactation period, we postulate that there is likely to be a decreased perfusion into the mammary glands secondary to a decrease in plasma volume expansion during severe dietary restriction and, thus, decreased nutrient transport. Effects of some dietary restrictions on milk yield and solute concentration have been reported previously by others. It has been reported that milk production by dams acutely malnourished during lactation was more severely reduced than was that of chronically malnourished dams (Warman \& Rasmussen, 1983; Young \& Rasmussen, 1985). Grigor et al. (1987) reported reduced milk production in dams fed on a low-protein diet $(100 \mathrm{~g}$ casein $/ \mathrm{kg})$ during gestation and up to day 7 of lactation when compared with dams fed on a control diet $(200 \mathrm{~g}$ casein $/ \mathrm{kg})$. Thus dietary restrictions during pregnancy and lactation could markedly influence the rate of milk production.

Composition changes due to undernutrition have also been reported. In previous studies, milk from malnourished dams had a higher protein and fat concentration and a lower water content when compared with milk obtained from the stomachs of their suckling pups (Fellows \& Rasmussen, 1984). However, similar differences in solute concentrations were not observed between milk from well-nourished dams and the stomach milk curds of their young. With regard to vitamin A, Young \& Rasmussen (1983) observed an increase in milk vitamin A concentration in rats restricted to $50 \%$ of normal food intake, even though the total amount of vitamin A delivered to the pups, as determined by the vitamin $\mathrm{A}$ concentration of milk obtained from the pups' stomachs, was reduced to only $61 \%$ of control. In agreement with these observations (Young \& Rasmussen, 1983), our dams severely restricted in either total food or fat or protein, or both, had higher milk vitamin A concentrations in milk samples than dams fed on the control diet ad lib. Differences in vitamin A concentration were not apparent in the stomach contents; however, the mass of 
milk curd in the stomachs of pups suckling from restricted dams was greatly reduced. Similarly, the concentration of vitamin A in the livers of 14-d-old pups from restricted dams was not reduced and, indeed, in some cases was somewhat elevated. Yet, taking into account the smaller liver size of these undernourished pups, the total vitamin A accumulation was significantly reduced, averaging $37 \mathrm{nmol}$ for the control pups (46 nmol/liver on day 14 minus $9 \mathrm{nmol} / \mathrm{liver}$ on day 2, Table 6) but only 12-23 nmol for pups nursed by dams fed on the three restricted diets. From these lower hepatic reserves and the reduced content of stomach milk, it may be inferred that the total transfer of vitamin A from the dam to her pups was reduced significantly. Furthermore, it is reasonable to speculate that dietary rehabilitation of these severely malnourished neonates with protein or energy, or both, without vitamin supplementation could, by improving growth, hasten the depletion of their meagre vitamin A stores. Subsequent consequences might include further growth impairment, ocular manifestations, and decreased resistance to infection. For example, we have shown that vitamin A deficiency reduces the immune response to certain bacterial antigens (Pasatiempo et al. 1989; A. M. G. Pasatiempo and A. C. Ross, unpublished results).

In addition to poor mammary gland development and organ perfusion, other factors causing reduced nutrient delivery to the young are likely to include lethargy of the pups, as we noted in study 2 ; and impaired absorptive efficiency (Olson, 1986). Although the usual indices of maternal vitamin A status (serum vitamin A concentration and liver retinol concentration) were not abnormal in the malnourished dams in our study, these animals exhibited an inability to provide normal quantities of vitamin A, as well as other nutrients necessary for growth, to their developing and suckling young.

This project is supported by NIH grant HD-16484. A.C.R. is the recipient of a NIH Research Career Development Award, HD00691.

\section{REFERENCES}

Baker, H., Frank, O., Thomson, A. D., Langer, A., Munves, E. D., De Angelis, B. \& Kaminetzky, H. A. (1975). Vitamin A profile of 174 mothers and newborns at parturition. American Journal of Clinical Nutrition $28,59-65$.

Brown, K. H., Akhtar, N. A., Robertson, A. D. \& Ahmed, M. G. (1986a). Lactational capacity of marginally nourished mothers: relationships between maternal nutritional status and quantity and proximate composition of milk. Pediatrics 78, 909-919.

Brown, K. H., Robertson, A. D. \& Akhtar, N. A. (1986b). Lactational capacity of marginally nourished mothers: infant's milk nutrient consumption and patterns of growth. Pediatrics 78, 920-927.

Ceriani, R. L. (1974). Hormones and other factors controlling the growth of the mammary glands. Journal of Investigative Dermatology 63, 93-108.

Clinton, S. K., Imrey, P. B., Alster, J. M., Simon, J., Truex, C. R. \& Visek, W. J. (1984). The combined effects of dietary protein and fat on 7,12-dimethylbenz(a)anthracene-induced breast cancer in rats. Journal of Nutrition 114, 1213-1223.

Dann, W. J. (1932). The transmission of vitamin A from parents to young in mammals. Biochemical Journal 26, 1072-1080.

Davila, M. E., Norris, L., Cleary, M. P. \& Ross, A. C. (1985). Vitamin A during lactation: relationships of maternal diet to milk vitamin A status of lactating rats and their pups. Journal of Nutrition 115, $1033-1041$.

Fellows, W. D. \& Rasmussen, K. M. (1984). Comparison of methods for obtaining milk samples from wellnourished and malnourished rats. Physiology and Behavior 33, 761-763.

Gebre-Medhin, M., Vahlquist, A., Hofvander, Y., Uppsall, L. \& Vahlquist, B. (1976). Breast milk composition in Ethiopian and Swedish mothers. I. Vitamin A and beta carotene. American Journal of Clinical Nutrition 29, $441-451$.

Grigor, M. R., Allan, J. E., Carrington, J. M., Carne, A., Geursen, A., Young, D., Thompson, M. P., Haynes, E. B. \& Coleman, R. A. (1987). Effect of dietary protein and food restriction on milk production and composition, maternal tissues and enzymes in lactating rats. Journal of Nutrition I17, 1247-1258.

Laga, E. M., Driscoll, S. G. \& Munro, H. N. (1972a). Comparison of placentas from two socio-economic groups. I. Morphometry. Pediatrics 50, 24-32. 
Laga, E. M., Driscoll, S. G. \& Munro, H. N. (1972b). Comparison of placentas from two socio-economic groups. II. Biochemical characteristics. Pediatrics 50, 33-39.

Mancini, G., Carbonara, A. O. \& Heremanns, J. F. (1965), Immunochemical quantitation of antigens by single radial immunodiffusion. Immunochemistry 2, 235-254.

McLaren, D. S., Shirajian, E, Lashkajian, H. \& Shadarevian, S. (1969). Short-term prognosis in protein-calorie malnutrition. American Journal of Clinical Nutrition 22, 863-870.

National Research Council Subcommittee on Laboratory Animal Nutrition (1978). Nutrient Requirements of the Laboratory Rat no. 10. Washington, DC: National Academy of Sciences.

Nelson, M. M. \& Evans, H. M. (1953). Relation of dietary protein levels to reproduction in the rat. Journal of Nutrition 51, 71-84.

Olson, J. A. (1986). Physiological and metabolic basis of major signs of vitamin A deficiency. In Vitamin A Deficiency and its Control, pp. 19-57 [J. C. Bauernfeind, editor]. Orlando, Florida: Academic Press.

Pasatiempo, A. M. G., Bowman, T. A., Taylor, C. E. \& Ross, A. C. (1989). Effects of vitamin A depletion and repletion on antibody response to the capsular polysaccharide of Streptococcus pneumoniae, type III (SSS-III). American Journal of Clinical Nutrition 49, 501-510.

Pereira, S. M., Begum, A. \& Dumm, M. E. (1966). Vitamin A deficiency in kwashiorkor. American Journal of Clinical Nutrition 19, 182-186.

Reddy, V. \& Srikantia, S. G. (1966). Serum vitamin A in kwashiorkor. American Journal of Clinical Nutrition 18, $105-109$.

Rogers, A. E. (1979). Nutrition. In The Laboratory Rat, pp. 123-150 [H. J. Baker, J. R. Lindsey and S. H. Weisbroth, editors]. New York: Academic Press.

Rosso, P. (1977). Maternal-fetal exchange during protein malnutrition in the rat. Placental transfer of glucose and a non-metabolizable glucose analog. Journal of Nutrition 107, 2006-2010.

Rosso, P. (1981). Nutrition and maternal-fetal exchange. American Journal of Clinical Nutrition 34, 744-755.

Rosso, P., Keyou, G., Bassi, J. A. \& Slusser, W. M. (1981). Effect of malnutrition during pregnancy on the development of the mammary glands of rats. Journal of Nutrition 111, 1937-1941.

Rosso, P. \& Streeter, M. R. (1979). Effects of food or protein restriction on plasma volume expansion in pregnant rats. Journal of Nutrition 109, 1887-1892.

Sklan, D. \& Ross, A. C. (1987). Synthesis of retinol-binding protein and tranthyretin in yolk sac and fetus in the rat. Journal of Nutrition 117, $436-442$.

Steimmetz, J. E., Romano, A. G. \& Patterson, M. M. (1981). Statistical programs for the Apple II microcomputer. Behavioral Research of Methods and Instrumentation 13, 702.

Takahashi, Y. L., Smith, J. E., Winick, M. \& Goodman, D. S. (1975). Vitamin A deficiency and fetal growth and development in the rat. Journal of Nutrition 105, 1299-1310.

Warman, N. L. \& Rasmussen, K. M. (1983). Effects of malnutrition during the reproductive cycle on nutritional status and lactational performance of rat dams. Nutrition Research 3, 527-545.

Winick, M. (1970). Cellular growth in intrauterine malnutrition. Pediatric Clinics of North America 17, 69-78.

Young, C. M. \& Rasmussen, K. M. (1983). The effect of the severity of chronic malnutrition on lactational performance and nutritional status of rats. Federation Proceedings 42, 922, Abstr. 3689.

Young, C. M. \& Rasmussen, K. M. (1985). Effects of varying degrees of chronic dietary restriction in rat dams on reproductive and lactational performance and body composition in dams and their pups. American Journal of Clinical Nutrition 41, 979-987. 